University for Business and Technology in Kosovo

UBT Knowledge Center

Oct 28th, 9:00 AM - 10:30 AM

\title{
Revitalization of the Kokalari Estate within the historic context of Gjirokastra
}

Severin Karl Valentin Queck

Technische Universität Wien, severin.queck@googlemail.com

Follow this and additional works at: https://knowledgecenter.ubt-uni.net/conference

Part of the Architecture Commons

\section{Recommended Citation}

Queck, Severin Karl Valentin, "Revitalization of the Kokalari Estate within the historic context of Gjirokastra" (2017). UBT International Conference. 14.

https://knowledgecenter.ubt-uni.net/conference/2017/all-events/14

This Event is brought to you for free and open access by the Publication and Journals at UBT Knowledge Center. It has been accepted for inclusion in UBT International Conference by an authorized administrator of UBT Knowledge Center. For more information, please contact knowledge.center@ubt-uni.net. 


\title{
Revitalization of the Kokalari Estatewithin the historic context of Gjirokastra
}

\author{
Severin Karl Valentin Queck \\ Technische Universität Wien, Austria \\ Faculty of Architecture and Spatial Planning \\ Department of Building History and Research \\ severin.queck@googlemail.com
}

\begin{abstract}
In the historic center of the UNESCO World Heritage site of Gjirokastra lie the remains of one of the town's most notable family-residences. Built in 1883, the edifice owns an extraordinary composition for the late Ottoman period. Today, the ruin is a memorial site dedicated to Musine Kokalari, who spent her youth in Gjirokastra. She was declared a "National Heroine" years after her death in 1983 for her defiant stand against the totalitarian regime. This paper exposes the factors, which endanger the monument and explicates the necessary operations for a successful revitalization following the ideas of Arjeta Kokalari, curator of the "Muzeu Kokalari”.
\end{abstract}

Keywords: preservation of cultural heritage, ottoman architecture, revitalization, contemporary architecture, museum and education

\section{Introduction}

During the authors first visit to Albania in 2016 a profoundly investigation about the local architecture in historic sites as well the conservation techniques and methods started to be undertaken. Another longer stay particularly in Gjirokastra followed in April and May 2017 to continue the scientific work at the UNESCO World Heritage Site. The author focused on the actual challenges of conserving historic buildings in Gjirokastra and the numerous threats, which endanger the built heritage. Interviews with experts were undertaken and precise documentations collected. The gained insights and partly alarming results are part of the current written master thesis by the author titled "Muzeu për Musine - Revitalization of the Kokalari Estate within the Historic Context of Gjirokastra". The document describes the current situation and condition of the world heritage site and compares the Albanian conservation methods with the international principles and guidelines for conservation focusing on the idea of implementing contemporary architecture within the historic center. Therefore, the advantages of new housing and public concept of use are presented and the given law on the world heritage of Gjirokastra is criticized. The explanations become completed by a proposal for the new design of "Muzeu Kokalari".

\section{Current Condition of Gjirokastra}

The extraordinary typology and composition of Gjirokastra's residential buildings are unique for the Ottoman architecture. When the influence of landowners in the region reached its peak in the beginning of the $19^{\text {th }}$ century, people erected the finest and most extended estates. Until now their built heritage endured and can be seen at examples like the house of Zeko or Skenduli. Back in 
those times the daily threat of blood feud forced the locals to construct their homes not only for living purposes. At that time J.G. v. Hahn compared the town's dwellings with the Occidental urban castles, in which lords controlled their entourages like a knight. Indeed, the high rising stone buildings show massive defense characteristics with fortified features like arrow slits, forecourts and high surrounding walls. ${ }^{18}$ Emin Riza divides the Banesa Gjirokastrite into three types. The simplest construction forms a rectangular residential tower (kullë), which can contain up to three floors. This basic element can be enlarged by a reseated extension defining the second type with one wing for more space. The third variant of Gjirokastra's residential buildings contains two wings and developed to most magnificent estates. ${ }^{19}$ The basic construction technique with broken lime stone and wood combines all mentioned types of the Banesa Gjirokastrite.

\section{The UNESCO World Heritage Site}

The old town of Giirokastra received its title as UNESCO World Heritage in 2005. Since then the town and the country of Albania hold a notable responsibility according to the "International Convention on the Protection of the Cultural and Natural Heritage of the World"20. In 2008, the listed site was extended by the old town and castle of Berat, $70 \mathrm{~km}$ north of Gjirokastra. Two of the totally six criteria required for the admission into the exclusive list of world heritage sites were fulfilled. The "outstanding testimony to the diversity of urban societies in the Balkans, and the longstanding ways of life which have today almost vanished" as well as the "outstanding testimony to various types of monument and vernacular urban housing during the Classical Ottoman period, in continuity with the various Medieval cultures which preceded it..." are decisive reasons for the protection of both towns. ${ }^{21}$

A common method of defining monuments on the Balkans is the subdivision into two categories. Back in the 1960s, 57 houses were declared as monuments of first category within the newly founded museum city of Gjirokastra. Those edifices have a very high historical-cultural value. They must be protected entirely from the outer composition and architecture as well as the inner furnishing and division. Another 593 buildings belong to category II, which classifies them in a lower level of values, but awards importance to the ensemble characteristics of the heritage site. ${ }^{22}$

\section{Reasons and Challenges for the Build Heritage}

In 2015, Elena Mamani from Cultural Heritage without Borders (CHwB) in Albania completed a condition assessment for the build heritage in Gjirokastra together with the Local Directory for National and Cultural Goods (DRKK) and the EPOKA University. The aim was to analyze all 658 monuments and classify them regarding interventions by necessity. ${ }^{23}$ Every building was registered and listed with descriptions and photos. The following diagrams show clearly the results for the main investigated categories.

\footnotetext{
${ }^{18}$ Hahn $1854,41 \mathrm{f}$

${ }^{19}$ Riza 2009, 245-250

${ }^{20}$ comp. http://www.unesco.de/infothek/dokumente/uebereinkommen/welterbe-

konvention.html

15.06.2017

${ }^{21}$ comp. http://whc.unesco.org/en/list/569, 24.01.2017

22 comp. Condition Assessment and Categorization for Interventions 2015

${ }^{23}$ interview with Elena Mamani, 23.05.2017
} 


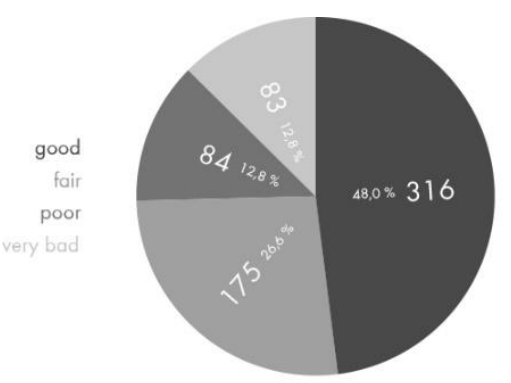

CONDITION

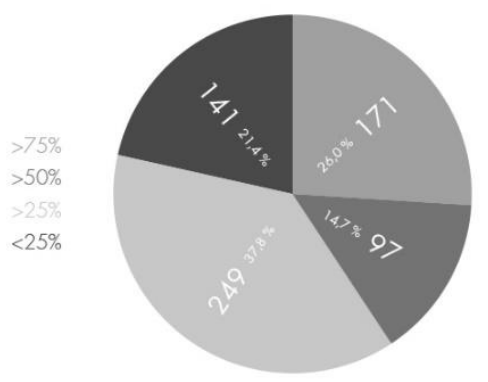

HISTORICAL CONTENT

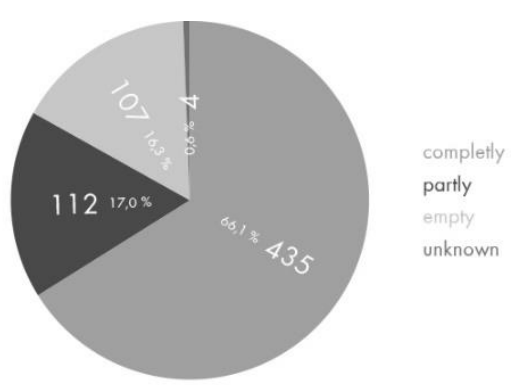

USAGE

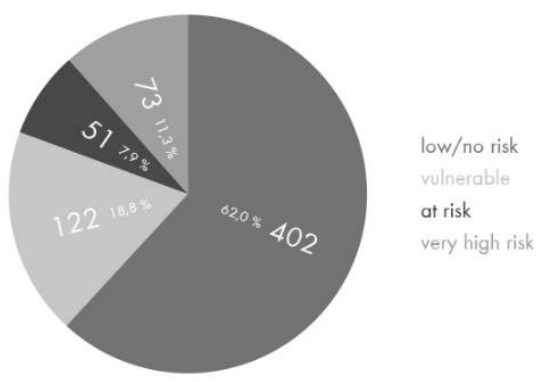

RISK CATEGORIZATION

Fig. 8. Diagrams are about the current situation of Gjirokastra's monuments

Numerous circumstances further the poor condition of the world heritage in many sites: not carried out maintenance of the roofs threatened by strong effects of weather, social phenomena like emigration followed by vacancy, undeclared or complicated property relationships or missing sensitivity for the historical substance. Additionally, uncontrolled construction business and unprofessional restoration works as well as a doubtable legislation and understaffed state authorities endanger the monuments in the town. Especially extern experts criticize the missing strategy of the government for the protection and conservation of Albania's historic buildings. Albert Kasi, director of the DRKK in Gjirokastra, had to admit, that the institute's method was directed by the fact, which emergency is currently mostly in need of an intervention. ${ }^{24}$ Therefore, foreign actors like the Swedish NGO of $\mathrm{CHwB}$ follow a much more farsighted and sustained method. Not only the team of international skilled experts for conservation and management are a sure advantage for this organization, but also their discovery of the bottom-up-strategy in protecting and promoting the cultural heritage by including the locals. With educational and information campaigns the institution fulfills to sustain and long-lasting result in their work. The aim is to make the owners and residents sensitive for their monuments to recognize their values to a utilization. This shall secure the preservation of Gjirokastra's monuments. ${ }^{25}$

\footnotetext{
24 interview with Albert Kasi, 25.05.2017

${ }^{25}$ interview with Lejla Hadžić, 19.05.2017
} 


\section{The Kokalari Estate}

Before discussing the Albanian conservation methods and the legislation in the context of international guidelines and principles for conservation, the following two subchapters describe the ruin of the monument, which marks the focus of the author's diploma thesis. Furthermore, the history of the family members, who lived in the estate of Kokalari and especially Musine Kokalari are the topic of this part.

\section{The Kokalari House}

Among the grand, Ottoman residential buildings, transformed monuments and ruins the towerlike edifice of the Kokalari estate protrudes from the steep ground in the upper part of the Palorto quarter. Entering from the road one passes a wild garden with vineyards, hydrangeas, roses, cypresses and smaller trees, which is laid on several terraces and is covered by dense vegetation. An olive tree, which is surrounded by a stone bench, grows in the center of this complex. The view from this place falls over the terrace's edge towards the town and continues until the mountains after the valley on the opposite side. The imposing structure itself is compact and massive. The ground floor as well as the level above are made of rough limestone, while the top level is clad with white plaster. According to the classic Ottoman style, the light openings, which penetrate the thick stonework, expand upwards, until they form three large windows in the top floor. On the right, a small unit fits into the main volume, which receives the entrance, entered through a stone staircase. The house expands to the rear, whose roof is completely lost. The residential tower represents the first, perpendicular variant of the Banesa Gjirokastrite resembling the Kullë. It reveals it structure particularly in the interior of the building, since the subdivisions are no longer existing today. The monument opens an eleven-meter-high hall, opened to the sky after years of decay and a fire during restoration works in 2014.

\section{The Kokalari Family in Past and Presence}

During the author's first visit in Gjirokastra, he could meet Arjeta Kokalari, the only family member of Kokalari living in the town. There are another five owners of the Kokalari House from her family. Arjeta was born May 141970 in Gjirokastra. Today the mother of three works in the local postal administration in the bazaar not far from her home. Her great passion, however, relates to the life and history of Musine Kokalari. Arjeta's attention belongs to the promotion of Musine's work and heritage as well as the political discourse of the first Albanian writer, who was made a "Martyr of Democracy" by the Hoxha regime for her social-democratic views, for the Albanian people. As a curator Arjeta wants to create a place at the Kokalari House, which serves for the debate and the processing of the almost fifty-year-longing cruelty of the communist regime. The phenomenon of being forgotten frightens people like Musine Kokalari nowadays. Musine Kokalari spent her youth in the same house in the property of the family together with her parents and brothers, before she moved to Italy to study. In the 1940s the estate was expropriated by the regime and new residents occupied the buildings. Through a tragic family drama, the house fell into disrepair until it was profoundly transformed in 1970. But it was only in the 1990s, when the old house was returned to the descendants of Reshat Kokalari, Musine's father. In 2004, Arjeta and her family started to take care of the house. The following years, restoration works were carried out and a new garden was planted. But only two months after completing the restoration of the monument, on 21 November 2014, a short circuit in the old roof truss started a fire, which quickly spread over the whole building. Shortly after, the home of Arjeta's family was destroyed entirely. Having lost a decade of investment and work, the curator 
didn't stop to publish and transfer Musine's manuscripts. The museum became digitalized and distributed in the social networks. Until today Arjeta follows her aim to tell the people about Musine's fight during the communist era and guides visitors in the Kokalari House. ${ }^{26}$

\section{Albanian Conservation Methods in the Context of the International Principles and Guidelines}

This chapter compares Albanian legislation for the cultural heritage with the international agreements and understanding of conservation. The focus will be the debate about the impact of contemporary architecture within the historical center of Gjirokastra.

\section{The Albanian Legislation for Cultural Heritage}

The current Albanian legislation for cultural heritage from $2015^{27}$ seems to follow all aspects of conserving and securing historical substance. It describes a model solution, which ranges from financing to the implementation of interventions by experts. But the document is still almost unfulfillable in its action for Albania. However, the law also explicitly opposes the construction of new buildings. Those are buildings, whose modern appearance would impair the protected cityscape. The consequences not only entail construction blocks, but also the suppression of contemporary construction solutions. This creates a counter-reaction by illegal transformations without construction guidelines, that can be seen in more than half of the monuments. In addition, the law defines empty sites in the historical center as viewing points or green areas, ${ }^{28}$ which means that this function is not only surpassed by the steadily growing free areas, so the construction sites in the center are left to the population and their benefit. A younger phenomenon, which has also been enshrined in the legislation, represents the historicizing "ottomanized" interventions. They are mistakenly titled as "restoration" or "reconstruction", but must be clearly rejected from modern conservation, because of their single imitating vision. Instead of authentic-integer urban development, they merely create a deceptively clichéd cityscape.

Moreover, more than half of the residences of the World Heritage have experienced transformations until their monumental value was completely lost. ${ }^{29}$ Persistent historical elements and structures inside the buildings of the second category are also to be preserved, but not reconstructed. Changes and modernizations are therefore permissible, if they do not impair the external appearance. ${ }^{30}$ Beside the illegal and unauthorized transformations, by law the inhabitants of first category monuments must preserve the buildings in their total historical appearance. ${ }^{31}$ In addition to the already mentioned causes for the poor state of preservation of Gjirokastra's monuments, problems arise. On the one hand the legislation guarantees the protection of the historical buildings, but on the other hand it puts those above the well-being and the demands of the users. Consequently, illegal transformations threaten the monuments. Thus, the question emerges, why state regulations do not meet the requirements with a modern lifestyle

\footnotetext{
26 interview with Arjeta Kokalari, 09. \& 10.05.2017

${ }^{27}$ Council of Ministers Albania, DECISION No. 619, date 7.7.2015

${ }^{28}$ DECISION No. 619, Art. 9

29 comp. Condition Assessment and Categorization for Interventions 2015

${ }^{30}$ DECISION No. 619, Art. 12

${ }^{31}$ DECISION No. 619, Art. 11
} 
of its inhabitants. However, the continuous use and the resulting value of historical buildings are the key to a lasting vitalization of the historical center of Gjirokastra.

\section{Comparison with International Principles and Guidelines for Conservation}

Despite considerable similarities, such as the so-called Nara Document (1994) or the Venice Charter (1964), the Albanian conservation practice differs in two points from the international guidelines: the definition of the integral and authentic substance as well as the admitting of new structures in the historical context. International institutions such as UNESCO or ICOMOS regard modern interventions, which are also critical, but recognize their need for the prosperity of a city. ${ }^{32}$ The starting point of the investigation into the Kokalari property is the realization, that the built environment has always been a changing and developing organism, which has reacted to changing circumstances in the past, to influences and above all to humans. In fact, in almost every world heritage site and settlement there are buildings from completely different centuries, architectural eras and cultures side by side. The cultural development in architecture thus never experienced a definitive end in history. Why should one not follow this way in the Gjirokastra of the 21 st century?

The director of the local DRKK asked the fundamental question: "Why do we need [contemporary architecture]?"33. As a government employee, he was far from criticizing the Albanian legislation. At the same time, however, he opened his ignorance of the fact that, in the international context, contemporary architecture was already tolerated in world heritage sites even by UNESCO. But authorities responsible for conservation see contemporary architecture under the pretext of a widespread prejudice against the architecture of the 21 st century: a bunker, a shoe box or a log, which is widely disliked by the civilian population.

\section{Contemporary Architecture within Historical Sites}

Therefore, the question arises: why and how can contemporary architecture in the historical context of Gjirokastra represent a surplus value for the world heritage and lead to the revitalization of urban life for its inhabitants? This can be discussed on two levels: the objectspecific, individual level and the urban, contextual level. The first one refers to monuments, whose owners are predominantly private persons or a multiple-ownership. The aim of making buildings useable must be to reconcile the historical substance with a contemporary lifestyle. Both sides should keep the balance, since the use of the monument is indispensable for its continuation. Modern but essential installations such as heating, electricity and sanitary are necessary, whose conversion or rebuilding has been refused because of historical elements, so far. At the same time, and seemingly contradictory, the cultural heritage must be protected and preserved. The different residential buildings of Gjirokastra are the result of a continuous adaptation of the monument typology to the requirements of its respective time. To interrupt this continuity already demanded serious consequences for the cultural heritage. It needs a sustainable strategy, which keeps space for the development of future requirements in the living environment. At the level of the ensemble or the urban space, it is essential to integrate components for a modern lifestyle in the historical structure without destroying Gjirokastra's center as an outstanding testimony of an Ottoman city. These include utilities, transport, services and public facilities. The late medieval Ottoman buildings can largely not provide such functions, because they were not built for this purpose. In addition, they are not suitable for certain uses such as supermarkets, schools or health centers due to their size or architecture. Today the bazaar is still

32 Bickert 2015, 119

${ }^{33}$ interview with Albert Kasi, 25.05.2017 
the public center of the old town, which is, apart from a few small local shops, a pharmacy and the post office as well as restaurants, primarily stocked for tourism. Basic needs of the inhabitants are rarely covered and further the emigration into the new districts in the valley. The numerous free sites, which were to be converted into parks according to legislation, would be available for new building types. Innovative solutions for transport and mobility should be reflected as well, to intervene cautiously in the built environment. But the demolition of monuments must not be tolerated with the replacement of a new building. Interventions on existing buildings as well as new buildings in an established context should, however, bear the stamp of this time and not imitate a nostalgic past, but clearly separate from it without dissolving the ensemble in harmony. This challenging and difficult urban development, which is acknowledged to be its historical heritage, should be tackled in Gjirokastra now.

\section{Idea and Concept of the new "Muzeu Kokalari"}

This is also based on the concept of the new "Muzeu Kokalari". The house of Musine's youth is to be revived after the fire disaster of 2014 and to offer locals and visitors a place where they experience something about the person Musine Kokalari as well as about their democratic values, which she defended in the time of the communist dictatorship and for which she was punished with imprisonment and isolation for the rest of her life. In addition, the "Garden of Memory", as Arjeta Kokalari calls it, together with the contemporary extension, will provide exhibition spaces and a library on the essence of socialism in Albania. Through additional conversations and events, visitors should be allowed to process the past as well as share the stories that people did not tell for so long.

The idea for the concept for the Muzeu Kokalari consists of three main sections: the historical remains of the main house, the garden with its terraced levels and the extension in contemporary shape. For the ruins of the monument, the author proposes a major repair. In contrast to a pure reconstruction, the restoration of the outer shell, the roof and the façade with its traditional windows and doors, should be the primary goal in accordance with the architecture of the late nineteenth century in Gjirokastra. The far-reaching transformations of communist times, which resulted in the loss of almost all historical substance inside and changes in the opening behavior of the outer walls, also represent a damage to the Kokalari house, as is the fire catastrophe. A complete restoration of the building to an Ottoman monument is intentionally to be avoided. At the same time, the tragedy of 2014 can also be transformed into an opportunity for the new museum. As already mentioned, the building now consists of a large hall inside, which strengthens the tower character. The newly acquired space, unique in a historical monument of Albanian-Ottoman architecture, will now make the future use of the museum appropriate. The former dwelling house now provides generous areas, which also remind of the fire as part of the history as well as part of the constant danger of the Banesa Gjirokastrite. The monument receives its roof back. The construction is to be reconstructed according to traditional techniques and covered with stone shingles. The openings in the masonry are to be restored at their original place and preserved by the historical model of wooden windows. The main entrance will also be reestablished in the original position. In the interior, the part of the exhibition, which deals with the family history and Musine Kokalari herself, is proposed. As the former residence of the family, it is necessary to exhibit in the same place the fate of the Kokalaris who lived there. 


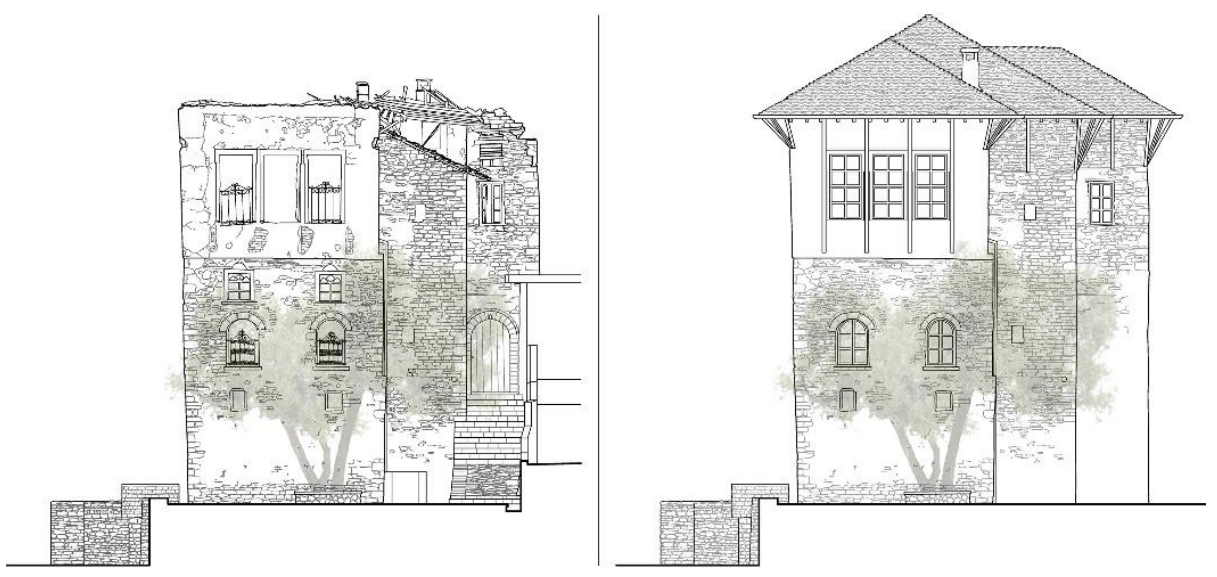

Fig. 2. Main façade of the Kokalari House now and after the major repair

An expansion of the Muzeu Kokalari for a larger offer is planned. The curator Arjeta, in addition to the family-historical part, wishes to have rooms reserved for the essence of socialism in Albania in the $20^{\text {th }}$ century. Her aim is to offer the people and, above all, the young generation a place where they can find both clarification and the processing what happened. A space for events or special exhibitions as well as a library supplement the museum's use of the new building. Architecturally, the design concept translates the guiding ideas of the historical Gjirokastra house in a contemporary way. The typical morphology and the use of limestone on façade and roof are used in a modern building technology. The aim is to harmoniously integrate the new building into the historical context and to revert to traditional elements. However, a clear difference will be seen in the execution and application of the local materials. The tower, from whose top level, the library gives a special view through a large opening in the otherwise rather closed building, is oriented to the Drino Valley and the opposite mountain chain.

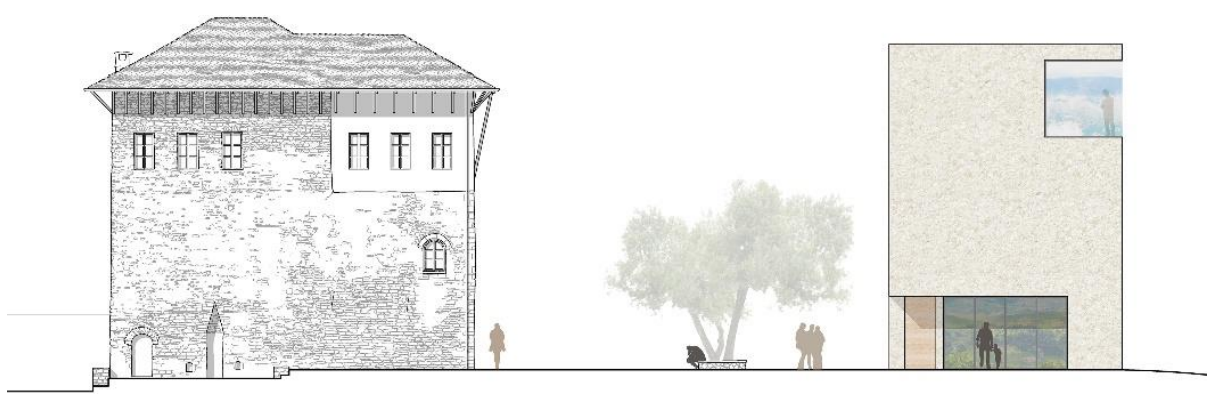

Fig. 3. Elevation of the new "Muzeu Kokalari" as in the status of the design process

Between the two separate buildings grows an old olive tree. It defines the center of the "Garden of Memory". This forms the third section of the museum. The garden is to become a peaceful oasis, on whose terraces the cultural offer can be extended. Various open-air zones can provide places for private conversation, meditation, or prayer. It connects the old and the new building. If one crosses the street in Palorto, where the property is located, the garden of Muzeu Kokalari is extended. In this part, where cypresses and olive trees grow, a small cafe and a shop are created, where the visitors can buy books written by the family and other authors. 


\section{Conclusion}

The future of the Kokalari House is very uncertain today. Both domestic policy and domestic family factors make it difficult to revitalize the monument and further the decay of the ruin. However, the theoretical examination of the conservation practice in Albania as well as the hypothetical proposal for the Muzeu Kokalari should not primarily target the realization of the project. Rather, it is necessary to start the discussion in the professional world and to focus on the debate about contemporary architecture within Albania's cultural heritage sites as well as the introduction of international principles and guidelines for the preservation of monuments. Sustainable development and the protection of historical centers such as Gjirokastra or Berat have made innovative approaches to solutions more important than ever before.

\section{References}

1. BICKERT, Matthias: Welterbestädte Südosteuropas im Spannungsfeld von Cultural Governance und lokaler Zivilgesellschaft. Untersucht am Beispiel Gjirokastra (Albanien). Bamberg, University of Bamberg Press (2015)

2. CHwB Albania, DRKK, EPOKA University: Condition Assessment and Categorization for Interventions. Gjirokastërs (2015)

3. Council of Ministers Albania, DECISION No. 619: For Proclaiming "Historic Center" of an Area in the City of Gjirokastra and Approval of the Regulation "on the Protection, Integrated Conservation and Management of the Historical Center and the Protected Area in the City of Gjirokastra“. Tirana (07.07.2015)

4. HAHN, Johann Georg von: Albanesische Studien. Jena (1854)

5. RIZA, Emin: Qyteti dhe Banesa Qytetare Shqiptare Shek. XV-XIX. Tirana (2000, 2009)

6. Übereinkommen zum Schutz des Kultur- und Naturerbes der Welt http://www.unesco.de/infothek/dokumente/übereinkommen/welterbekonvention.html 15.06.2017

7. UNESCO in URL: http://whc.unesco.org/en/list/569 24.01.2017

8. interview with Elena Mamani, Gjirokastra 23.05.2017

9. interview with Albert Kasi, Gjirokastra 25.05.2017

10. interview with Lejla Hadžić, Berat 19.05.2017

11. interview with Arjeta Kokalari, Gjirokastra 09. \& 10.05.2017 